\title{
The Validity Development of Adobe Flash Based Learning Media at Energy Conversion Machine Course in Vocational Education Programs
}

\section{Uswatun Hasanah ${ }^{1 *}$, Nizwardi Jalinus², Hasan Maksum³}

1,2,3 Universitas Negeri Padang, Indonesia

\section{A R T I C L E I N F 0}

Article history:

Received 15 August 2019

Received in revised Form 29 September 2019

Accepted 18 October 2019

Available online 29

November 2019

Keywords:

Energy Conversion

Machine, Learning Tools, Validity

\begin{abstract}
A B S T R A C T
Learning outcomes of Diploma 3 students of Mechanical Engineering in the Energy Conversion Engineering course seem not optimal, it estimated that the learning outcomes were not optimal due to the inaccurate use of learning media in the learning process. The purpose of this study was to produce a valid adobe flash based learning media.This research was Research and Development (R\&D) method with ADDIE model. The research subjects were students of the Diploma 3 Mechanical Engineering who took Energy Conversion Engineering courses. Data collect in the form of questionnaire sheets and primary data were obtained from lecturers and students. Data were analyzed by descriptive analysis technique by describing validity of adobe flash based learning media. Based on the analysis of the data obtained the validity of adobe flash based learning media, declared valid on the Content aspect with score 0,85 and the Display aspect with score 0,91. Based on the findings of this study it was concluded that the adobe flash based learning media was valid as a learning media in the Energy Conversion Machine course.
\end{abstract}




\section{Introduction}

Education is one of the most important parts that serve to create a new generation of quality. This begins with the learning process, so that learning activities become more effective and can obtain the desired results, the teacher's active role is needed. One way teachers can do to support their active role is by the use of instructional media. The use of instructional media is needed so that students are able to capture the subject matter properly. According to Nana Sudjana and Ahmad Rivai (2011: 1) instructional media are teaching aids in the component of the teaching methodology, as one of the learning environments arranged by the teacher. Whereas Oemar Hamalik (2013: 201) argues that the media is a human existence that allows influencing others who do not have direct contact with him.

Information and Communication Technology (ICT) is a tool or facility that provides needs in all environments, including physical infrastructure, generation, transmission, storage and processing (NoorUl-Amin, 2013). In addition, according to Ghaznavi, Keikha and Yaghoubi (2011) ICT is a tool for computer communication facilities. From the understanding of Information and Communication Technology (ICT) above, ICT has a very important role and can be used wherever and whenever and the output can reach its users at a low cost and in a short time in all users. To prepare students for 21st century challenges in the industrial world, the integration of ICT in learning must be carried out, the use of ICT tools and the application of technology must be supported (Lewin and Mcnicol, 2015). An educator must be able to create a good learning environment, so that students can be responsible for their own learning, focusing on certain processes and outcomes as expected in the 21st century.

A good learning environment occurs when the learning process can be carried out well too. The learning process has a meaning as the delivery of messages or information, which is carried out by educators to their students. Submission of this information has a flow that is from the source of information, the media used and recipients of information. At the time of learning, interactions occur among educators and students and learning tools, then the delivery of information by educators based on predetermined subject matter (Sri Ratu Rahayu, 2017). Learning tools or assistive devices are all tools used to facilitate students in implementing the learning process so that learning is expected to be more effective and efficient. Learning media are tools or learning materials needed by students to stimulate students' attention, interests, thoughts and feelings in learning activities to achieve learning goals (Melda Subri, 2016).

Learning media is the most important part of learning. Zainal Arifin and Adhi Setiyawan (2012: 126) argue that learning media and learning methods have the same important position, because the learning methods used in the teaching and learning process will usually demand what media can be adapted and integrated in learning according to the conditions in the field. The 2013 curriculum is one of the government programs in the world of education. In addition, the 2013 curriculum has been oriented towards student-centered learning (student center) which will require a media that can facilitate students in learning. In applying the principle of learning, the student center also uses computer-based learning. However, the application of computer-based learning has not been utilized to the maximum extent possible and teachers do not vary in presenting learning media and technology (Novrizen Eri, 2016). Therefore, taking advantage of the media in learning will certainly facilitate the process of interaction and communication between the teacher and students. The use of instructional media is expected to stimulate the senses of hearing and vision in order to increase student interest and learning outcomes in learning (Melda Subri, 2016).

Universitas Negeri Padang (UNP) is one of the leading state universities in the city of Padang. UNP has 9 faculties, one of which is the Faculty of Engineering in Diploma III (D3) of Mechanical Engineering. Energy conversion machine course is one of the compulsory subjects in D3 in mechanical engineering with 2 SKS. Based on observations, there are still low student learning outcomes in the energy conversion engine course. This evidenced by the D3 student grades in the energy conversion machine course in all classes / groups of the 2015/2016 academic year, 2016/2017 and 2018/2019 with Figure 1. 


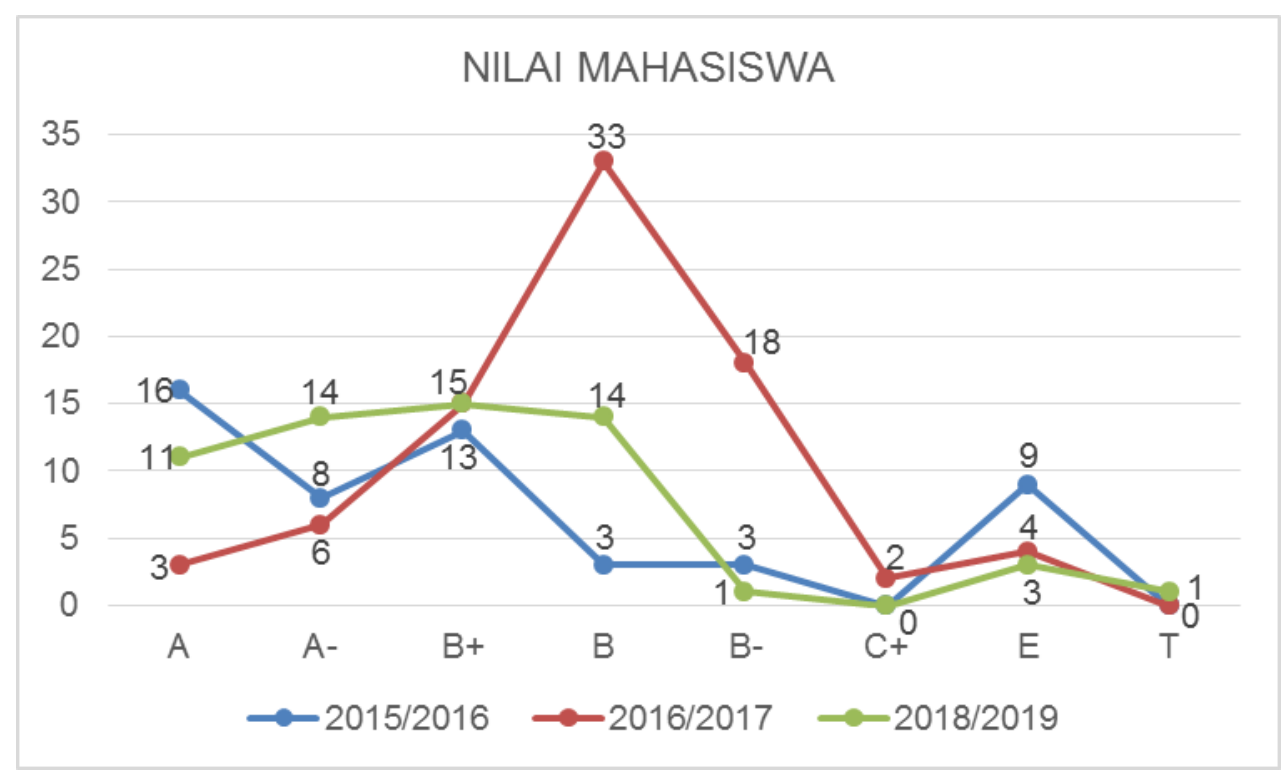

Figure 1. Student scores in Energy Conversion Machine course

Based on Figure 1, the student's result can be concluded that the learning outcomes of D3 mechanical engineering students in energy conversion machine course is still low. This evidenced by the largest percentage in 2016/2017 academic year with a B grade quality of $40.8 \%$, while the increase occurred in the 2018/2019 academic year with a B + quality value. This students not being able to master lecture material optimally, so that it affects the student learning outcomes.

Based on observations (interviews) that researchers have done at the Universitas Negeri Padang (UNP) on January 21, 2019, especially in D3 students of mechanical engineering and lecturers in the Energy Conversion Machine (MKE) course. The learning process has implemented PjBL learning, but the delivery of material by lecturers to students still exists using a printed module with blackboard. The absence of learning media that can arouse the enthusiasm and activeness of students in the classroom when learning, so that in the learning process students become less enthusiastic. Based on interviews conducted by researchers with students, the learning process in the energy conversion machine course is less attractive because there are still lecturers who have not applied the learning media based on Information Technology (IT), besides that students feel boredom in undergoing the learning process. The core of the subject matter is not well understood because the media that describe the subject matter in particular the working principle of the combustion engine and tubin water through simulation, there are still lecturers who have not applied it to the learning media. As in the special material, it discusses the work of fossil fuel combustion systems and the working principle of water turbines (action turbines and reaction turbines) which explains how to work and machine parts need to be shown through a simulation, there are still lecturers who have not applied it to learning Media. Besides that, according to the lecturer who taught the energy conversion machine course in D3 in mechanical engineering, there were still lecturers who had not utilized the learning media by simulating the working principle of the combustion engine and water turbine because the lecturer was still having difficulty in preparing media that could support the learning process in the classroom.

The demands of the learning process in the modern era are now all demanded to be easily accessible, innovative and fast. This is in line with the provisions of the Regulation of the Minister of Education and Culture of the Republic of Indonesia No. 65 of 2013 point 13 regarding the standardization of the vocational education process which explains: the use of information and communication technology in learning media to improve the efficiency and effectiveness of learning. Therefore, to overcome the problem in the energy conversion machine learning process in D3, mechanical engineering is to use information technology for the development of instructional media. As a tool in the learning process, information technology is used to facilitate the delivery of information / messages from lecturers to students. The advantage of the media that will be developed through information technology is the display of material can be presented attractively so that it can attract students' interest and attention. It can be assumed that learning will succeed if it starts from feeling happy and liking the material being studied. 
One of the ICT media that is able to concretize the message conveyed by the teacher to students is macromedia flash, macromedia flash is able to convey teacher's explanations that are abstract (Kusuma Pranoto, 2015). Furthermore Kusuma stated that "learning macromedia flash is used as a source of learning science in improving student learning, flash is one of the media that can be used by teachers in optimizing teaching and learning". The application of flash animation in the teaching and learning process in the classroom helps students understand the material, because it looks interesting in the form of animation, motion animation will arouse the motivation for classroom activity (Giriyanti, 2011). Furthermore Giriyanti stated that "flash can be used in making interactive and animative learning media in terms of appearance and also hits in terms of purpose because with the presence of interesting media will make student learning interest increase". Flash-based software is one of the information and communication technologies which can be used in making learning media. Researchers chose Adobe Flash Professional CS6 as one of the software that can create flash files.

Andi Pramono and Muhammad Syafii (2016: 6) argue that the Adobe company, Inc. has one of the software namely Adobe Flash Professional CS6 which is often used by most users because of its superiority which can produce everything related to making games, presentations, websites, banners commercials, cartoons and others. Adobe Flash Professional CS6 software is one software that can be used in making learning media which includes making animation, making presentations by inserting multimedia in the form of sound, images with ease of operation. Flash animation-based learning media can motivate student learning and be able to construct new knowledge through the senses of sight and hearing (Artanto Widhiya, 2011). So by developing media using Adobe Flash Professional CS6 Software will assist lecturers in explaining learning material. In research on the development of energy conversion learning machine learning media using Adobe Flash, which focuses on the work material of fossil fuel combustion systems and the working principle of water turbines (action turbines and reaction turbines). In developing this learning media there is an animation of the working principle of the combustion engine and water turbine. So that the animation of the learning media can improve the understanding of the material delivered by lecturers and can attract students' attention in learning.

Testing the feasibility of adobe flash-based learning media in the energy conversion machine course, the media that will be developed first is validated by expert judgment as a material expert, media expert and prospective media user namely lecturers and D3 students of mechanical engineering. Based on the learning aspects and material aspects, the material expert gives a statement worthy or not feasible developed media. Whereas based on aspects of language, aspects of ease, aspects of writing (text) and aspects of appearance, the media experts provide an assessment of the media being developed. Furthermore, lecturers and students provide an assessment after the media is validated by the validator, lecturers and students function as prospective users of the developed media. Elsa Novyarti's research results (2014) states that learning media using Adobe Flash can increase students' learning interest, so that the learning media can be used by educators and students. In addition, Adobe Flash can also produce some animations so that the results of animations are made not boring (Dewantara, 2014). As for the purpose of the developed media, they are given suggestions and assessments, so as to produce useful and interesting learning media according to the desired goals so that they can be applied in the learning process. in the classroom. With the advantages possessed by Adobe Flash Professional CS6 software it also makes it easier for students to understand the concept of energy conversion machine learning.

\section{Methods}

This research is a research and development (R\&D) research. According to Sugiyono (2015: 297) the research and development method is a method that use to produce certain products and testing the effectiveness of these products. Nusa Putra (2012: 67) describes research and development as research that systematically aims to produce, develop, improve, formulate, discover, test the effectiveness of products, procedures, strategies, methods, certain models that are newer, meaningful, productive, efficient and effective.

The development model used in this study is the ADDIE model which consists of 5 stages, there are Analysis, Design, Development, Implementation and Evaluation which was revealed by Sugiyono (2015: 200) . The ADDIE development model proposed by Bambang Warsita (2011: 7) is more effective, dynamic and supports product performance that involves expert judgment so that the writer interested in choosing this model. The stages of developing the ADDIE model are shown in Figure 2 as follows: 


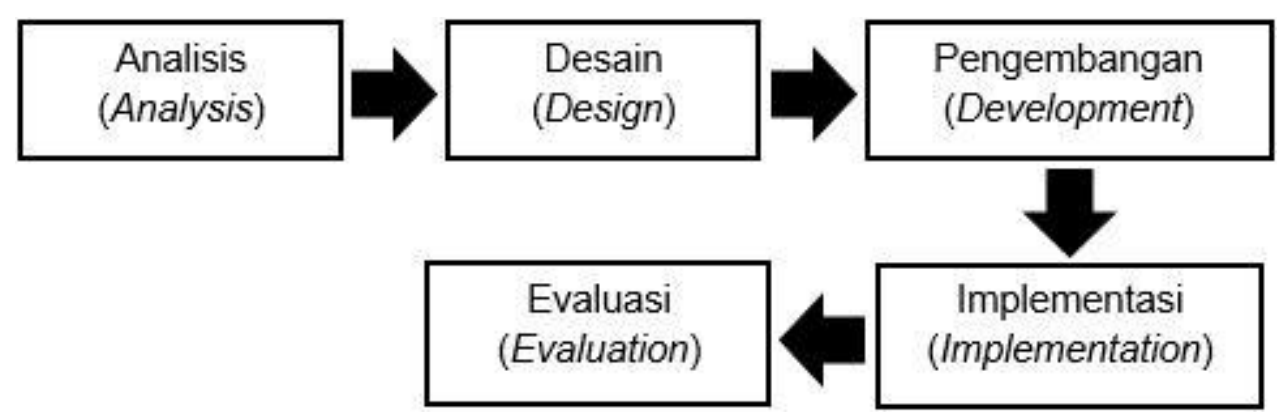

Figure 2. The Stages Of Developing The ADDIE Model

Validation test included in the third stage, called Development stage. The aim at this stage of development is to produce a revised Adobe Flash based learning media based on expert input. This stage is to validate the adobe flash-based learning media.

The validity test stage is an assessment of the design of a product. Sugiyono product validation (2015: 302) is carried out by several experts or experts who are experienced with the product, so that the expert can assess the weaknesses and strengths of the product produced. Adobe Flash-based learning media that have been designed, consulted and discussed with experts or experts, then the design assessed by competent people (validators) who have understood the principles of developing adobe flash-based learning media.

Products to be validated are divided into two, there are: content (material) and display (media). Validation activities carried out in the form of filling in the adobe flash-based learning media validity questionnaire. The validation process obtained scores and suggestions from the validator as a guidelines in making improvements to products, so there is an improvement in the adobe flash-based learning media in the energy conversion machine course.

\section{A. Validation Instrument}

The validation instrument developed to collect data in this study is a questionnaire of adobe flash based learning media by the validator. Sugiyono (2015) defines a questionnaire sheet as a list of questions or statements that must be filled in by respondents to be evaluated. The validation questionnaire consisted of Content validation and Display validation.

Material aspects related to the process of find the truth concepts in accordance with the curriculum applied, the suitability of media content with lecture material by referring to the Lecture Event Unit (SAP) of the course that has been formulated. On the lattice of the material expert instruments, aspects consists of aspects of learning and material related to the learning media material developed, so that the truth of the content broke down into 15 items.

While the aspects of media related to aspects of the use of images, sound, text, video and message presentation in the manufacture of adobe flash-based learning media. The media expert instrument lattices, while the aspects consist of language, convenience, writing (text) and display related to the learning media developed and can be broke down into 20 items.

Each validation questionnaire contains an assessment and response to the material working principle of the combustion engine and water turbine for D3 students in mechanical engineering.

\section{B. Validation Analysis}

Material and media validation analysis based on the results of the validator's assessment. Data obtained through a questionnaire, then analyzed using Aiken's V. statistics The results of Aiken's V calculations ranging from $0-1$ and 0.667 numbers can be interpreted to have high enough coefficients, then $\mathrm{V}$ values of 0.667 and above are stated in the valid category. The validity analysis category can be seen in Table 1. 
Table 1. Validity Analysis Categories

\begin{tabular}{ccc}
\hline No & Achievement Level & Category \\
\hline 1 & $0,667-1,00$ & Valid \\
2 & $<0,667$ & Not Valid \\
\hline
\end{tabular}

The steps of validity analysis as follows; The validator gives a rating score for each indicator on a scale from 1-5 with the following provisions: 5 (very good), 4 (good), 3 (good enough), 2 (not good) and 1 (not good). Then add up the scores from each validator for all indicators. Furthermore, providing validity values calculated using Aiken's V statistics by Saifuddin Azwar (2015: 113) is formulated as follows:

$$
\mathrm{V}=\sum \mathrm{s} /[\mathrm{n}(\mathrm{c}-1)]
$$

Information:

$\mathrm{S}=\mathrm{r}-\mathrm{lo}$

Lo $=$ lowest validity rating number (in this case $=1$ )

$\mathrm{c}=$ highest validity rating (in this case $=5$ )

$r$ = score given by the validator

\section{Result And Discussion}

Adobe Flash based learning media is a teaching delivery system that presents material by listening, viewing video and sound through computer control to students so that learning was more effective. The purpose of the adobe flash-based learning media validation test was developed to find out the feasibility based on the assessment of Content experts and Display experts.

The validation test data obtained from the validation instrument which filled by several validators who were Content experts and Display experts. The validator also entitled to provide input to the learning material and media developed, then the input can be used as a revision for researchers in the development of this Adobe Flash-based learning media. The results of the assessment given from each validator were analyzed using the statistical formula Aiken's V. The following was the result of the analysis of the questionnaire data from the results of expert validation testing:

\section{A. Content Validation}

Material expert validation is a validation of the material produced and validated by three material experts, included two lecturers majoring in mechanical engineering D3 and one lecturer in energy conversion machine lectures at the Faculty of Engineering, Universitas Negeri Padang. The results of material validation can be seen in Table 2 .

Table 2. The Results of Material Validation

\begin{tabular}{clccc}
\hline No & & Indikator & Aiken's V & category \\
\hline 1 & Learning & 0,83 & Valid \\
2 & Theory & 0,86 & Valid \\
\hline \multicolumn{2}{c}{ Total } & $\mathbf{0 , 8 5}$ & Valid \\
\hline
\end{tabular}

Table 2 show that the average score of material validation assessment obtained from the three validators is 0.85 with the category "valid". This proves that the adobe flash-based learning media is appropriate to be used as a learning medium in the energy conversion engine course.

\section{B. Validasi Tampilan (Media)}

Media expert validation is a validation carried out on the product design that is produced and validated by three media experts. The three media validators were Postgraduate lecturers at the Faculty of Engineering, Universitas Negeri Padang. The results of media validation can be seen in Table 3. 
Table 3. Media Validation Results

\begin{tabular}{|c|c|c|c|}
\hline No & Indikator & Aiken's V & category \\
\hline 1 & Language & 0,92 & Valid \\
\hline 2 & Ease & 0,90 & Valid \\
\hline 3 & Text & 0,94 & Valid \\
\hline 4 & Display & 0,90 & Valid \\
\hline & Total & 0,91 & Valid \\
\hline
\end{tabular}

Based on Table 3 show that the average score of media validation assessment obtained from the three validators is 0.91 with the category "valid". This proves that the adobe flash-based learning media is appropriate to be used as a learning medium in the energy conversion engine course.

Thus it can be concluded that the development of adobe flash-based learning media developed has met all aspects of the required criteria.

This research was a research and development with the ADDIE (Analysis, Design, Development, Implementation, Evaluation) development model. The product was adobe flash-based learning media, which applied to students of D3 class on Wednesday session on energy conversion machine courses in D3 of mechanical engineering at Universitas Negeri Padang with a total of 28 students.

Discussion of the results of the development that has been carried out then further described, especially relating to the validity of the learning media developed. Further discussion is described as follows:

\section{The Development of Learning Media Based on Adobe Flash}

Based on the analysis that has been done, the development of adobe flash-based learning media was developed to answer various learning problems that occur in the D3 mechanical engineering course of energy conversion machines, where the problem causes low student interest in learning so it has implications for low learning outcomes. In addition, the development of learning media is also due to the unavailability of learning media that can facilitate students to learn. By using this learning media students can easily learn learning materials in accordance with a predetermined curriculum that is equipped with learning facilities including learning materials, animations, videos and practice exercises.

The learning process of the adobe flash-based learning media starts from the analysis, design, development, implementation and evaluation stages. In the analysis phase several activities were carried out, namely observation, curriculum analysis, analysis of student characteristics and material analysis. This stage is done as a basis for developing adobe flash-based learning media in the energy conversion engine course. After conducting the analysis phase, it is obtained adobe flash based learning media which is used for sub learning outcomes of energy conversion machine subjects. This learning sub-achievement is divided into several indicators, namely, analyzing various types of power machines that use various types of energy sources, energy conversion and various energy change processes that are beneficial to human survival, and analyzing various types of energy conversion machines / devices that use different types of energy sources water potential.

The next stage is the design, at this stage the adobe flash-based learning media is based on the analysis that has been done at the analysis stage, designed as best as possible to suit the needs of students. After the design phase is carried out, then the adobe flash-based learning media is carried out the development stage which aims to produce a valid adobe flash-based learning media according to experts, practically viewed from the user's side, namely lecturers and students, and effectively used to solve problems contained in the conversion machine course energy. After the development phase, the implementation phase of the learning media is being developed for D3 students of mechanical engineering. The last stage is evaluation, aiming to improve the adobe flash-based learning media at each stage, at this stage formative and summative evaluations are conducted. This learning media will later be accessed using a computer or laptop offline. After the adobe flash-based learning media was developed, then a validity test was conducted on the learning media.

\section{The Validity of Learning Media Based on Adobe Flash}

In determining whether a learning media is valid or not, it is necessary to test the validity first. According Suharsimi Arikunto (2010: 121) "A validity test is carried out to find out whether the measuring instrument has accuracy in measuring or in other words whether the measuring instrument 
can truly measure what is to be measured". The validation of adobe flash-based learning media is obtained from the validator responses about the validity of the learning media developed. The validator consists of 5 people, namely three people from the material validator and three people from the media validator. Data from the validator is obtained from the validity questionnaire filled out by each validator in accordance with the actual situation when the media and material that has been developed are shown to the validator to be checked and provide input on things that must be improved so that the material and media that have been developed become better. and ready to use.

The first step taken was the validation of the material contained in the adobe flash-based learning media, the material that was already available on the learning media was assessed by material experts consisting of 2 lecturers majoring in mechanical engineering D3 and 1 lecturer in energy conversion machine lectures. So the average percentage value given by the three material validators is 0.85 in the "Valid" category. The results of this validation indicate that the adobe flash-based learning media developed are in accordance with the curriculum used today. In line with research (Nurhayati, 2017) based on the validation of material experts on the suitability of the assessment of material presented in interactive media to achieve learning objectives, material experts stated that the material in interactive media $85.71 \%$ was appropriate.

The second step taken is the validation of learning media, indicators of validation regarding language, convenience, writing (text) and appearance. Learning media in the form of adobe flash-based learning media are shown to the media validator to assess its validity. After evaluating the validation by filling out a questionnaire by the validator, the data from the validator is summarized and the validity value obtained from each validator is sought. Overall, the average validity value for adobe flash-based learning media from the three validators was 0.91 in the "valid" category. With the results obtained by the average value of the validator, it can be concluded that the adobe flash-based learning media developed are valid and are as expected. In line with research (Nurhayati, 2017) based on ahlimedia validation to assess interactive media both from the appearance and function of instructional media in enhancing students' critical thinking skills in learning, media experts stated that $92 \%$ interactive media was appropriate.

Based on the evaluation of the validator above, both in terms of the material or the media contained in the learning media, it can be concluded that the adobe flash-based learning media developed are feasible to be used in teaching and learning in energy conversion machine courses in D3 in mechanical engineering Padang State University. This is consistent with the opinion of Nieveen Mckenney (2006: 144) that "validity is the first aspect that must be met from the development of quality learning media so that products can be used by teachers and students". While validity (validity) according to (Nursalam, 2013) is a measurement and observation which means the principle of instrument reliability in data collection.

\section{Conclussion}

Based on the results of research and development of adobe flash-based learning media that has been done, the following conclusions obtained. This study use ADDIE development models, there are the analysis, design, development, implementation and evaluation stages. The subjects of the development were students of the D3 Department of Mechanical Engineering Universitas Negeri Padang. This learning media helps students understand the lessons that contain text, images, animations / simulations and videos in the material on the energy conversion machine course that can increase student motivation and learning outcomes. This learning media was developed using the Adobe Flash Professional CS6 application which is offline. Adobe Flash-based learning media in the energy conversion engine course was declared by experts as a valid learning medium through content (material) and display (media) aspects.

Based on the research conducted, the following things are suggested. Bagoes can use adobe flashbased learning media as a support to the learning process, which is useful to support the improvement of student learning outcomes, for students after using this adobe flash-based learning media is expected to be more active in the learning process so that it encourages potential in improving learning performance and for other researchers to carry out the development of learning similar things in learning materials, and other subjects. 


\section{Reference}

Andi Pramono dan Muhammad Syafii. 2016. Kolaborasi Flash, Dreamweaver dan PHPuntuk Aplikasi Website. Jakarta: Areli.

Artanto Widhiya. 2011. "Pengembangan Bahan Belajar Berbasis Audio Visual”. Tesis. Digital Repository Unila.

Bambang Warsita. 2011. Pendidikan Jarak Jauh: Perancangan, Pengembangan, Implementasi dan Evaluasi Diklat. Bandung: PT Remaja Rosdakarya.

Dewantara. 2014. "Pengembangan Animasi Flash dan Soal Interaktif Berbasis Power Point pada Materi Sistem Pernapasan Manusia Kelas XI". Tesis. Digital Repository Unila.

Elsa Novyanti. 2014. "Pengembangan Media Pembelajaran Menggunakan Adobe Flash dan Autoplay Media Studio dalam Pembelajaran yang Berbasis Inquiry pada Materi Garis dan Sudut Kelas VII SMP". Tesis. Universitas Jambi.

Ghaznavi, M. R., Keikha, A. and Yaghoubi, N. M. 2011. The Impact of Information and Communication Technology (ICT) on Educational Improvement. International Education Studies,4(2), 116-125. https://doi.org/10.5539/Ies.v4n2p116.

Giriyanti. 2011. Pemanfaatan Animasi Flash Sebagai Media. Diakses Rabu 2 September 2019.

Kusuma Pranoto. 2015. "Pengaruh Macromedia Flash Terhadap Hasil Belajar Siswa Kelas X IPA SMA Negeri 4 Pasuruan". Tesis. Universitas Muhammadiyah Malang.

Lewin, C. and Mcnicol, S. 2015. Supporting The Development of 21st Century Skills Through ICT. KEYCIT 2014: Key Competencies in Informatics and ICT, 98-181.

Melda Subri. 2016. "Pengembangan Media Pembelajaran Berbasis Adobe Flash CS3 dalam Mata Pelajaran Teknologi Informasi dan Komunikasi di Kelas XI SMAN 16 Padang”. Tesis. PPS FT-UNP.

Nana Sudjana dan Ahmad Rivai. 2011. Media Pengajaran (Penggunaan dan Pembuatannya). Bandung: Sinar Baru Algensindo Offset.

Nieveen, N., Mckenney, S and Akker, J.V.D. 2006. Educational Design Research: The Value of Variety. Dalam Akker, J.V.D., Gravemeijer, K., Mckenney, S. \& Nieveen, N (Eds.). Educational Design Research (hlm. 144-184). Enchede: Axis Media-Ontwerpens.

Noor-Ul-Amin, S. 2013. An Effective Use of ICT for Education and Learning By Drawing on Worldwide Knowledge, Research and Experience: ICT As A Change Agent for Education. International Journal of Scientific \& Technology Research, 2(9), 1-13. https://doi.org/6th August 2016.

Novrizen Eri. 2016. "Pengembangan Multimedia Interaktif Berbasis Adobe Flash pada Pelajaran Instalasi Jaringan LAN di Sekolah Menengah Kejuruan". Tesis. PPS FT-UNP.

Nurhayati. 2017. “Pengembangan Media Pembelajaran Interaktif Berbasis Animasi Flash untuk Meningkatkan Keterampilan Berpikir Kritis Siswa pada Materi Sistem Respirasi Manusia”. Tesis. Universitas Lampung.

Nursalam. 2013. Metodologi Penelitian Ilmu Keperawatan: Pendekatan Praktis. Jakarta: Salembamedika.

Nusa Putra. 2012. Research \& Development, Penelitian dan Pengembangan: Satuan Pengantar. Jakarta: PT. Raja Grafindo Persada. 
Oemar Hamalik. 2013. Proses Belajar Mengajar. Jakarta: PT Bumi Aksara.

Saifuddin Azwar. 2015. Metode Penelitian. Yogyakarta: Pustaka Pelajar.

Sri Ratu Rahayu. 2017. "Pengembangan Media Pembelajaran Berbasis Android Menggunakan Adobe Flash CS6 untuk Mata Pelajaran Matematika". Tesis. PPS FT-UNP.

Sugiyono. 2015. Metode Penelitian Pendidikan: Pendekatan Kuantitatif, Kualitatif dan R\&D. Bandung: Alfabeta.

Suharsimi Arikunto. 2010. Prosedur Penelitian Suatu Pendekatan Praktik. Rineka Cipta Jakarta.

Tata Usaha Jurusan D3 Teknik Mesin FT-UNP. 2019. Padang.

Zainal Arifin dan Adhi Setiyawan. 2012. Pengembangan Pembelajaran Aktif dengan ICT. Yogyakarta: Skripta Media Creative.s 